\title{
HUBUNGAN STRES KERJA DENGAN SIKAP EMPATI PERAWAT \\ MEDIKAL BEDAH RUMAH SAKIT SANTA ELISABETH \\ MEDAN TAHUN 2017
}

\author{
Lilis Novitarum $^{1}$, Samf riati Sinurat ${ }^{2}$, Marton Siant uri $^{3}$ \\ Program Studi Ners \\ STIKes Santa Elisabeth Medan
}

\begin{abstract}
ABSTRAK
Latar Belakang : Stres merupakan respon tubuh seseorang yang sifatnya non spesifik terhadap setiap tuntutan beban kerja yang berlebihan. Bila seseorang mampu mengatasi beban yang berlebihan tersebut dan tidak mengalami gangguan fungsi tubuh, maka orang tersebut tidak mengalami stres. Empati merupakan kemampuan untuk memahami apa yang orang lain rasakan dan pikirkan yang merupakan kemampuan dan keterampilan dalam memfasilitasi kesepakatan sosial dan berhasil menavigasi hubungan pribadi, hal ini penting untuk kelangsungan hidup individu karena memerlukan keakuratan dalam persepsi, interpretasi, dan respon terhadap emosi orang lain.Oleh karena itu empati merupakan sebuah blok bangunan penting untuk prilaku prososial, atau tindakan orang mengambil manfaat lain. Tujuan : Penelitian ini bertujuan untuk menganalisis hubungan stres kerja perawat dengan empati perawat kepada pasien dirumah sakit santa elisabeth medan tahun 2017.

Metode : Penelitian ini menggunakan pendekatan cross-sectional dengan teknik pengambilan sampel total sampling, sebanyak 29 responden.

Hasil : Berdasarkan uji statistik (chi-square) didapatkan $p$ value $=0,006$ ( $\mathrm{p}<0,06$ ) sehinggaadahubungansignifikanantaraStres Kerja Dengan Sikap Empati Perawat Medikal Bedah Rumah Sakit Santa Elisabeth Medan

Kesimpulan : Diharapkan agar Rumah Sakit mengadakan penyuluhan atau seminar tentang sikap empati dan dapat memberikan reward berupa material seperti pujian ataupun penghargaan bagi perawat yang memiliki rasa empati. Diruangan Medikal Bedah Rumah Sakit Santa Elisabeth Medan.
\end{abstract}

\section{Kata Kunci : Stress Kerja, Sikap Empati}

\begin{abstract}
Background : Stress is the response of a person's body that is non-specific to any excessive workload demands. When a person is able to overcome the excessive burden and does not experience disruption of body function, then the person is not experiencing stress. empathy is the ability to understand what others feel and think which is the ability and skill in facilitating social agreements and successfully navigating personal relationships, it is important for the survival of individuals because it requires accuracy in the perception, interpretation, and response to the emotions of others. Therefore empathy is an important building block for prosocial behavior, or the actions of people taking other benefits.
\end{abstract}


Goals : This study aims to analyze the relationship of nurses work stress with nurse empathy to patients in santa elisabeth field hospital in 2017.

Methods : This study used cross-sectional approach with sampling total sampling technique, as many as 29 respondents.

Result : Based on statistical test (chi-square) got $p$ value $=0,006(p<0,06)$ so there is significant relation between Work Stress With Empathy Attitude Medical Nurses Hospital Surgery Santa Elisabeth Medan

Conclution : It is expected that the Hospital holds counseling or seminars on empathy and can give rewards in the form of materials such as praise or awards for nurses who have a sense of empathy. Medical Surgery Room at Santa Elisabeth Hospital Medan.

Keywords: Work Stress, Empathy

\section{PENDAHULUAN}

Stres adalah respon tubuh seseorang yang sifatnya non spesifik terhadap setiap tuntutan beban yang berlebihan. Bila seseorang mampu mengatasi beban yang berlebihan tersebut dan tidak mengalami gangguan fungsi tubuh, maka orang tersebut tidak mengalamai stress. Sebaliknya, jika tidak mampu mengatasi beban yang berlebihan tersebut, mengganggu salah satu organ tubuh, maka seseorang tersebut mengalaami stress (Hawari, 2013).

Wijono (2014), mendefinisikan stres kerja sebagai suatu keadaan yang timbul dalam interaksi antara manusia dan pekerjaan. Hal yang sama juga disampaikan oleh Ratnaningrum (2012), mendefinisikan stres kerja merupakan suatu respon fisik atau emosi yang berbahaya dan terjadi ketika persyaratan dalam pekerjaan tidak seimbang dengan kemampuan, sumber daya atau kebutuhan kebutuhan dari pekerja. Stres kerja merupakan bentuk stres yang diakibatkan oleh suatu pekerjaan yaitu kondisi yang timbul akibat interaksi antara manusia dan pekerjaannya ditandai oleh diri organisasi tersebut yang menyebabkan penyi mpangan dari fungsinya yang normal. Dari kedua pendapat diatas, disimpulkan bahwa salah satu penyebab stres kerja adalah pekerjaan.

\begin{abstract}
Menurut American National Association for Occupational (2013), menempatkan kejadian stres kerja pada perawat berada diurutan paling atas pada empat puluh kasus pertama, yang disebabkan adanya stres dalam bekerja. Tingginya angka kejadian stres kerja pada perawat juga terlihat di Indonesia.

Hasil survei yang dilakukan oleh PPNI (Rosmawar, 2014), sekitar 50,9\% perawat yang bekerja di empat provinsi di Indonesia mengalami stres kerja yaitu sering pusing, lelah, tidak bisa beristirahat karena beban kerja tinggi dan menyita waktu sehingga pelayanan keperawatan kepada pasien tidak maksimal. Penelitian yang dilakukan oleh Simanjorang (2013), di RSUD Pringadi Medan didapatkan $59,6 \%$ perawat mengalami stres kerja yang mengakibatkan kurangnya empati perawat kepada pasien.
\end{abstract}

Selanjutnya penelitian yang dilakukan oleh Tobing (2013), di Ruang TB Paru RSUD Sidikalang Kabupaten Dairi Sumatera Utara didapatkan $41,7 \%$ perawat mengalami stres kerja. Setiap individu mengalami stres kerja dengan gejala yang bermacam-macam tergantung kondisi dan lingkungannya. Salah satu penyebabnya adalah ketidakadanya rasa empati.

Empati adalah kemampuan untuk memahami apa yang orang lain rasakan 
dan pikirkan yang merupakan kemampuan yang merupakan keterampilan penting dalam memfasilitasi kesepakatan sosial dan berhasil menavigasi hubungan pribadi. Hal ini penting untuk kelangsungan hidup individu karena memerlukan keakuratan dalam persepsi, interpretasi, dan respon terhadap emosi orang lain. Oleh karena itu empati adalah sebuah blok bangunan penting untuk prilaku prososial, atau tindakan orang mengambil manfaat lain (Segal, dkk, 2013). Empati pada diri seorang perawat secara tidak langsung akan mendekatkan hubungan emosional antara perawat dengan pasien, sehingga dengan adanya empati tersebut perawat akan senantiasa memberikan perawatan yang lebih baik dan dengan adanya empati dari perawat maka pasien akan merasa nyaman dan tenang dalam melaksanakan proses penyembuhan. Oleh karena itu empati yang dimiliki oleh seorang perawat akan mempengaruhi stres kerja perawat terhadap pasiennya (Allias, 2014).

Menurut penelitian Wilkin \& Silvester(2007), sikap empati dari seorang perawat sangat diperlukan agar hubungan saling percaya dapat terbina dan mempermudah untuk menggali permasalahan klien, serta mempercepat proses penyembuhan, terlebih lagi dalam berinteraksi dengan klien.

Perawat adalah profesi pekerjaan yang mengkhususkan diri pada upaya penanganan asuhan keperawatan kepada pasien dengan tuntutan kerja yang tergantung pada karakteristik-karakteristik tertentu dalam melaksanakan pekerjaannya yaitu, karakteristik tugas dan material seperti (peralatan, kecepatan, kesiagaan),karakteristik organisasi yaitu jam kerja/shift kerja, dan karakteristik lingkungan kerja seperti teman, tugas, suhu, kebisingan, penerangan, sosio budaya, dan bahan pencemar, Pelayanan profesional yang diberikan oleh perawat dalam sebuah rumah sakit membuatnya sering berinteraksi dengan pasien. Mereka seharusnya dapat menjalin komunikasi yang baik, dan mampu merasakan apa yang dirasakan pasiennya dan tidak hanya sekedar melakukan tugas rutin, memberi obat atau memandikan pasiennya (Nursalam, 2013).

Berdasarkan data Rumah Sakit Umum Pusat Klaten menunjukkan bahwa terdapat hubungan yang signifikan antara stres kerja dengan empati perawat kepada pasien dimana sebagian perawat yang mempunyai stres kerja berat, sebagian besar mempunyai sikap empati kerja dalam kategori sedang sebesar 20\%, dan stres kerja sedang, mempunyai sikap empati dalam kategori baik sebesar 48,3\%. Rumah Sakit Muhammadiyah Yogyakarta menunjukkan bahwa terdapat perawat dalam kategori sikap empati tinggi sebesar $62,5 \%$, yang kemudian diikuti perawat dalam kategori sikap empati sedang sebesar $35,7 \%$, dan perawat dalam kategori sikap empati rendah sebesar $1,8 \%$. Hal ini disebabkan karena perawat kurang bisa menunjukkan sikap empati, dan juga banyaknya tuntutan pekerjaan, karena akan menambahkan stres kerja perawat (Lusianawati, 2012).

MenurutAllias (2014), bahwa rumah sakit daerah Provinsi Sulawesi Selatan tingkat empati perawat di unit rawat Inap jumlah perawat sebanyak 31 orang diantaranya sikap empati perawat baik sebanyak 30 orang $(96,8)$ sedangkan yang tingkat empat perawat cukup sebanyak 1 orang $(3,2 \%)$.

$$
\text { Menurut Setiyana (2013), }
$$
mengatakan bahwa banyak ditemukan fenomena di rumah sakit adanya perawat yang tidak sabar, suka marah, berbicara ketus dengan pasien dan keluarga pasien, bahkan terjadi kelalaian dalam bekerja seperti kesalahan dalam pemberian obat, dan keterlambatan dalam melakukan injeksi. Hal ini tentu sangat berlawanan dengan tugas dan kewajiban sebagai seorang perawat yang harus memberikan pelayanan prima pada pasien.

Berdasarkan survey awal yang dilakukan dimana terdapat perawat yang kurang peduli kepada pasien dan juga data penunjang yang diperoleh dari Rumah 
Sakit Elisabeth Medan jumlah total perawat sebanyak 227 orang dengan jumlah tempat tidur 321 tempat tidur. Diruangan rawat medikal bedah khususnya ruangan Maria dan Martha terdapat sebanyak 49 tempat tidur dengan jumlah tenaga perawat sebanyak 35 orang, sedangkan jumlah standar tenaga perawat yang ditetapkan di ruangan maria dan martha rumah sakit santa elisabeth medan sebanyak 44 orang. Dimana per shift nya dinas tenaga perawat berjumlah 7 orang untuk shift pagi dengan 1 orang kepala ruangan, $1 \mathrm{CI}$ ruangan, 1 kepala tim, dan 4 perawat pelaksana. Untuk shift sore dan malam memiliki jumlah tenaga perawat hanya 3 sampai 4 orang saja. Berdasarkan data yang diproleh masih kurang jumlah standar tenaga perawat, yang mengakibatkan stres kerja meningkat dan dapat menyebabkan kurang nya empati perawat kepada pasien diruangan medikal bedah ( RSEM, 2017).

Sedikitnya jumlah perawat tidak sebanding dengan jumlah pasien sehingga beban kerja meningkat, yang dapat mengakibatkan stres kerja perawat. Sehingga mempengaruhi sikap empati perawat dalam melakukan pelayanan keperawatan dimana apabila perawat yang tidak memiliki rasa empati sangat mempengaruhi proses kesembuhan pasien, dan juga pasien akan tidak akan merasa nyaman selama proses pemulihan di rumah sakit tersebut dan pasien tidak puas dalam pelayanan yang didapatkan diruang bedah Rumah Sakit Elisabeth Medan.

Berdasarkan uraian diatas peneliti tertarik untuk meneliti lebih lanjut mengenai stres kerja perawat diruangan bedah Rumah Sakit Santa Elisabeth Medan untuk mengetahui sejauh mana hubungan stress kerja dengan sikap empati perawat kepada pasien.

\section{METODE PENELITAN}

Penelitian ini menggunakan desain cross-sectional yaitu suatu bentuk studi observasional (non-eksperimental) untuk menentukan hubungan antara faktor resiko dan penyakit, yang mencakup semua jenis penelitian yang pengukuran variabel hanya dilakukan satu kali, pada suatu saat (Sastroasmoro,2016) Didalam penelitian ini peneliti menganalisa apakah ada hubungan stress kerja yang di alami oleh perawat dengan sikap empati perawat kepada pasien.

Populasi adalah keseluruhan unit analisa yang penelitian atau objek yang diteliti (Notoadmojo, 2012). populasi dari penelitian ini adalah seluruh Perawat diruangan Maria dan Martha medikal bedah Rumah Sakit Santa Elisabeth Medan yaitu berjumlah 29 orang. (SDM RSE, 2017)Peneliti mengambil sampel dengan teknik total sampling yaitu cara pengambilan sampel dengan mengambil semua anggota populasi menjadi sampel, sehingga jumlah sampel pada penelitian ini adalah 29 orang sesuai dengan jumlah populasi.

Instrumen yang digunakan dalam penelitian ini dibuat dalam bentuk kuesioner. Kuesioner penelitian ini terdiri dari dua bagian yaitu stres kerjadan empati yang berisi data demografi (Nama initial, umur, pendidikan).

Dalam melakukan analisa data terlebih dahulu data harus diolah. Pengolahan data dapat dilakukan melalui 4 tahap, yaitu: editing, coding, scoring, tabulating.Penelitian ini menggunakan uji statistik dengan chi square yaitu untuk mengetahui adanya hubungan stres kerja dengan sikap empati perawat, dengan tingkat kepercayaanskala kategorik. Nilai p-value $<0,05$ maka dapat dihasilkan bahwa ada hubungan stres kerja dengan sikap empati perawatRuanganMedikalBedahRumahSaki tSanta Elisabeth Medan.

HASIL PENELITIAN

Tabel 1Distribusi Frekuensi Responden Berdasarkan Karakteristik Demografi Perawat Medikal BedahRumah sakit Santa Elisabeth Medan

\begin{tabular}{llll}
\hline Variabel & Kategori & $F$ & $(\%)$ \\
\hline
\end{tabular}




\begin{tabular}{llll}
\hline $\begin{array}{l}\text { Jenis } \\
\text { kelamin } \\
\text { Total }\end{array}$ & Laki-laki & 5 & 17,2 \\
Usia & Perempuan & 24 & 82,8 \\
& 20- & 28 & $\mathbf{1 0 0}$ \\
Total & 40Tahun & 1 & 3,4 \\
& 41- & $\mathbf{2 9}$ & $\mathbf{1 0 0}$ \\
& 60Tahun & & \\
\hline Suku & Batak & 21 & 72,4 \\
& Toba & 8 & 27,6 \\
Total & BatakKaro & $\mathbf{2 9}$ & $\mathbf{1 0 0}$ \\
Pendidikan & & 24 & 82,8 \\
& Akper & 5 & 17,2 \\
Total & Sarjana & $\mathbf{2 9}$ & $\mathbf{1 0 0}$ \\
\hline
\end{tabular}

Berdasarkan tabel 1. didapatkan bahwa mayoritas responden berjenis kelamin perempuan 24 orang $(82,8 \%)$, mayoritas berusia $20-40$ tahun 28 orang $(96,6 \%)$. Suku Batak Toba 21 orang $(72,4 \%)$ dan Batak Karo sebanyak 8 orang (27,6\%). Pendidikan Akademi Keperawatan (AKPER) sebanyak 24 orang $(82,8 \%)$ dan Sarjana sebanyak 5 orang $(17,2 \%)$.

Tabel 2.Distribusi Frekuensi Stress Kerja Perawat Medikal Rumah Sakit Santa Elisabeth Medan.

\begin{tabular}{lcc}
\multicolumn{1}{c}{ StresKerja } & $\boldsymbol{f}$ & $\mathbf{( \% )}$ \\
\hline Ringan & 16 & 55, \\
Sedang & 13 & 44,8 \\
Berat & 0 & 0 \\
\hline Total & $\mathbf{2 9}$ & $\mathbf{1 0 0}$ \\
\hline
\end{tabular}

Berdasarkan tabel 2. Stres kerja perawat diruang medikal bedah Rumah Sakit Santa Elisabeth Medan, ditemukan bahwa responden yang mengalami stress kerja dengan kategori berat tidak terdapat diruangan medikal bedah st.maria dan st.martha, sedang sebanyak 13 responden $(44,8 \%)$, ringan sebanyak 16 responden $(55,2 \%)$.

\section{Tabel 3.Distribusi Frekuensi DanPersentase Sikap Empati Perawat Medikal Rumah Sakit Santa Elisabeth Medan.}

\begin{tabular}{lll}
\hline SikapEmpati & $F$ & $(\%)$ \\
\hline
\end{tabular}

\begin{tabular}{lcc}
\hline Baik & 0 & 0 \\
Cukup & 12 & 41,4 \\
Kurang & 17 & 58,6 \\
\hline Total & $\mathbf{2 9}$ & $\mathbf{1 0 0}$ \\
\hline
\end{tabular}

Berdasarkan tabel 3 Sikap empati perawat diruangan medikal bedah $\mathrm{St}$. Martha dan St. Maria ditemukan bahwa responden sikap empati perawat dengan kategori baik tidak ditemukan pada perawat diruangan medikal bedah, sikap empati perawat dalam kategori cukup sebanyak 12 responden $(41,4 \%)$, sedangkan sikap empati perawat dalam kategori berat sebanyak 17 responden $(58,6 \%)$.

Tabel 4.TabulasiSilangStress kerja dan Sikap

PerawatMedikalBedahRumahSakitSant a Elisabeth Medan.

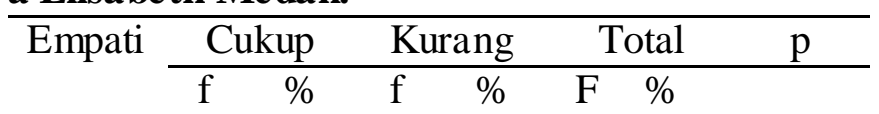

Stress

\begin{tabular}{|c|c|c|c|c|c|c|c|}
\hline Sedang & 9 & 31,0 & 4 & 13,5 & 13 & 44,8 & 0,006 \\
\hline Ringan & 3 & 10,3 & 13 & 44,8 & 16 & 55,2 & \\
\hline Total & 12 & $\overline{41,4}$ & 17 & 58,6 & 29 & 100 & \\
\hline
\end{tabular}
dapatkan jumlah pasien yang memiliki empati cukup dengan stress sedang ada 9 orang $(31,0 \%)$, empati cukup dan stress ringan ada 3 orang $(10,3 \%)$, pasien yang memiliki empati kurang dan stress sedang ada 4 orang $(13,5 \%)$ dan empati kurang dan stress ringan ada 13 orang $(44,8 \%)$. Setelah dilakukan uji chi square di dapatkan nilai $\mathrm{p}=0,006(\mathrm{p}<0,05)$. berarti ada hubungan stress kerja dengan sikap empati perawat kepada pasien di ruangan medikal bedah Rumah Sakit Santa Elisabeth Medan.

\section{PEMBAHASAN}

Stres kerja perawat kepada pasien diruangan medikal bedah Rumah Sakit Santa Elisabeth Medan.

Stress kerja perawat di Rumah Sakit Santa Elisabeth Medan dalam katagori Ringan. Dari 29 jumlah responden 
ada sebanyak 13 orang (44,8\%) mengalami stress kerja sedang, dan 16 orang $(55,2 \%)$ mengalami stres kerja ringan. Dilihat dari hasil penelitian bahwa stress kerja mayoritas ringan $(55,2 \%)$ di Rumah Sakit Santa Elisabeth Medan, hal ini di karenakan adanya sikap empati perawat yang mempersepsi dan merasakan perasaan orang lain.Menurut Hawari, (2013) Stres bisa dikatakan positif jika mempunyai dampak yang baik dengan meningkatkan motivasi dan kewaspadaan, namun stres yang negatif akan memberikan dampak yang sangat merugikan.Sebagai contoh sesorang yang baru mendapat jabatan bisa jadi merasa stres karena takut tidak dapat melakukan pekerjaan baruyang dipercayakan kepadanya sehingga orang tersebut termotivasi untuk dapat melakukan pekerjaannya dengan baik

Menurut peneliti diruangan St. Maria dan St. Martha dari hasil mayoritas stres kerja tingkat sedang $(44,8 \%)$ di dukung dalam penerapan stress kerja perawat yang mendukung seperti : "indikator fisik", Otot saya merasa kaku saat / setelah bekerja, seperti kaku dibagian leher, "indikator perilaku"Saya menyalahkan diri sendiri atau cenderung berbuat salah,. "indikator emosi"Saya terkadang merasa tertekan dan mudah marah tanpa sebab yang berarti. Hal ini didukung oleh hasil penelitian National safety council mengatakan bahwa tidak ada pekerjaan yang bebas dari stres, karena setiap pekerjaan memiliki beban, tantangan dan kesulitan sehingga seseorang yang mampu mempertahankan rasa pengendalian diri dalam lingkungan kerja akan menerima setiap urusan dalam pekerjaan sebagai suatu tantangan dan bukan ancaman. Hal inilah yang menyebabkan seseorang mengalami stres kerja.

Sikap Empati Perawat Kepada pasien diruangan medikal bedah Rumah Sakit Santa Elisabeth Medan.

Sikap empati perawat di Rumah Sakit Santa Elisabet Medan mayoritas kurang empati. Dari 29 jumlah responden ada sebanyak 17responden $(58,6 \%)$ dengan katagori sikap kurang empati, sedangkan sikap responden dengan kategori cukup empati sebanyak 12 responden $(41,4 \%)$.

Menurut Priyoto (2013), Empati seharusnya sudah dimiliki oleh remaja ketika menduduki akhir masa kanak kanak awal (6 tahun). karena kemampuan berempati sudah mulai muncul pada masa akhir kanak - kanak dan demikian semua individu memiliki dasar kemampuan untuk berempati hanya saja berbeda tingkat kedalaman dan cara mengaktualisasikan nya, Karenapikiran, kepercayaan, dan keinginanseseorang berhubungan dengan perasaannya, seseorang yang berempati akanmampu mengetahui pikiran dan mood oranglain.

Asumsi peneliti mengatakan dilihat dari sikap empati perawat kepada pasien Diruangan Medikal Bedah St.Martha dan St.Maria Rumah Sakit Santa Elisabeth Medan mayoritas kurang empati $(58,6 \%)$ dikarenakan seseorang yang berempati akanmampu mengetahui pikiran dan mood orang lain, oleh karena itu timbulnya kurang sikap empati perawat.Hal ini didukung dari pendapat dari Thomas dkk, (2008) menyebutkan semakin lama relasi seseorang semakin banyak pengetahuan tentang kepribadian dan sikap-sikap dari partner relasi. Pengetahuan dan pemahaman yang lebih akurat mengenai pemikiran dan perasaan partner relasi saat berinteraksi akan meningkatkan rasa empati.

\section{Hubungan stres kerja dengan sikap empati perawat kepada pasien diruangan me dikal bedah Rumah Sakit Santa Elisabeth Medan}

Hasil penelitian ini yaitu adahubungan yang signifikan antara stress kerja perawat dengan sikap empati perawat kepada pasien Diruangan Medikal Bedah Rumah Sakit Santa Elisabeth Medan dengan $p$ value $=0,006(<\alpha 0,05)$. 
Stres kerja yang dimaksud pada peneliti ini adalah merupakan suatu respon fisik atau emosi yang berbahaya yang diakibatkan oleh suatu pekerjaan yaitu kondisi yang timbul akibat interaksi antara pekerja. Berdasarkan penelitian menunjukkan responden yang memiliki stress kerja ringan terhadap perawat ditemukan karena adanya sikap empati yang kurang dari perawat kepada pasien berjumlah 16 responden (55,2\%), kemudian dari 29 responden menunjukkan stress kerja sedang dengan sikap empati perawat yang cukup sebanyak 13 responden (44,8\%). Adapun seorang perawat yang mengalami stress kerja dikarenakan adanya factor pendukung yaitu "Saya terkadang merasa tertekan dan mudah marah tanpa sebab yang berarti "Sedangkan sikap empati pada perawat mayoritas kurang empati", adapun factor yang mendukung yaitu seperti "Terkadang saya merasa peduli ketika pasien mengalami kesulitan, dan juga faktor faktor lain seperti masih belum ada nya penyuluhan tentang stress kerja dan sikap empati.

Hal ini tidak sejalan dengan pendapat Ahmad, (2009). Dimana penelitiannya mengatakan Kedua jenis antara stress kerja dan empati ini berhubungan dengan perasaan seseorang dalam hubungan dengan orang lain. Empati pengertian yang sederhana ialah suatu kecenderungan untuk ikut serta merasakan segala sesuatu yang sedang dirasakan orang lain dan dapat langsung memberikan antusiasme kepada penderita sementara apabila perawat yang mengalami stress kerja maka jelas empati perawat juga terganggu. Dengan kata lain, suatu kecendrungan stress kerja untuk ikut serta merasakan sesuatu yang dirasakan oleh orang lain dan membantunya. Seperti ada situasi feeling with another person, sedangkan, menurut hasil penelitian yang telah saya lakukan ternyata didapatkan dari 29 responden, perawat yang mengalami stress kerja ringan ternyata memiliki empati yang kurang/buruk. Hal ini dibuktikan dari hasil yang didapat melalui penelitian ini dimana stres kerja dalam kategori ringan dengan sikap empati kurang sebanyak $(55,2 \%)$ seperti yang terdapat di tabel 5.4

Hubungan antara stress kerja dengan sikap empati perawat kepada pasien dikatakan positif lemah, yaitu tidak menutup kemungkinan jika terjadi kenaikan pada variable stress kerja akan diikuti kenaikan variable sikap empati seperti pada penelitian ini. Sehingga menandakan bahwa stress kerja sedang maka sikap empati perawat juga akan semakin tinggi kepada pasien diruangan medikal bedah, begitu juga sebaliknya, apabila stress kerja perawat ringan dapat juga memperburuk sikap empatinyadiruangan medikal bedah St.Martha dan St.Maria. Ini ditandai dengan faktor - faktor lain yaiu adanya penyebab perawatyang kurang mendapatkan pendidikan ditandai dengan banyaknya jenjang pendidikan yang masih D3-Keperawatan, dan juga belum ada dilakukan penyuluhan tentang sikap empati perawat, di Rumah Sakit Santa Elisabeth Medan.

\section{SIMPULAN DAN SARAN Simpulan}

Dari hasil penelitian yang telah dilakukan dapat disimpulkan bahwa :

1. Perawat di Unit perawatan bedah Rumah Sakit Santa Elisabeth Medan, $(44,8 \%)$ mengalami stress kerja sedang.

2. Perawat di Unit perawatan bedah Rumah Sakit Santa Elisabeth Medan, ditemukan perawat yang memiliki sikap empati kurang terhadap pasien $(55,2 \%)$

3. Terdapat hubungan yang signifikan antara stress kerja dengan sikap empati perawat kepada pasien diruangan medikal bedah Rumah Sakit Santa Elisabeth Medan dengan nilai $p$ value $=0,006(\mathrm{p}<0,05)$. 


\section{Saran}

$\begin{array}{ccr}\text { Diharapkan } & \text { agar } & \text { Rumah } \\ \text { Sakitmengadakan } & \text { penyuluhan } & \text { atau }\end{array}$ seminar tentang sikap empati dan dapat memberikan reward berupa material seperti pujian ataupun penghargaan bagi perawat yang memiliki rasa empati. Dalam meningkatkan proses pemberian auhan keperawatan kepada pasien di Rumah Sakit Santa Elisabeth Medan, agar perawat yang bekerja khusus nya diruangan medikal bedah Rumah Sakit Santa Elisabeth Medan termotivasi dan berlomba berusaha untuk menjadi yang terbaik dalam pemberian proses asuhan keperawatan.

Diharapkan agar dapat digunakan sebagai referensi dalam menambah wawasan serta dapat digunakan sebagai bahan bacaan bagi mahasiswa STIKes Santa Elisabeth Medan.

Diharapkan kepada peneliti selanjutnya untuk melibatkan responden yang lebih banyak lagi dan mencakup keseluruhan pasien yang dirawat di Rumah Sakit Santa Elisabeth Medan.

\section{DAFTAR PUSTAKA}

Allias. (2014). Hubungan Stres Kerja Dengan Tingkat Empati Perawat Pada Pasien Perilaku Kekerasan Di Rumah Sakit Khusus Daerah Provinsi Sulawesi Selatan. https://jurnalstikesnh.files.wordpres s.com/2016/11/4414493500_23021721.pdf. Diakses pada tanggal 31 januari (2017).

American National Association for Occupational. (2013). http://client.com=national+associati on+of+occoptional+healthoch $3 \mathrm{~h} 2 \mathrm{gDH}$. Diakses pada tanggal 28 januari (2017)

Depkes, (2014). Upaya peningkatan mutu rumah sakit. http://id.scribd.com/pedomanpenin gkatan-mutu-rumahsakit-pd.

Diakses pada tanggal 28 januari (2017).

Dewi \& Wawan. Teori dan Pengukuran Pengetahuan, Sikap, dan Perilaku Manusia. Yogyakarta: Nuha Medika

Erawan. (2013). Hubungan Beban Kerja Perawat Dengan Empati Perawat Di Ruang Rawat Inap Medikal Bedah Rsup Dr. Soeradji Tirtonegoroklaten. https://journal.respati.ac.id/index.p hp/ilmukeperawatan/article/downlo ad/205/179. Diakses pada tanggal 2 februari (2017).

Hawari, Dadang. (2013). Manajemen Stres Cemas Dan Depresi. Jakarta : Fakultas Kedokteran Universitas Indonesia.

Hidayat. A (2009). Konsep-Kosep Dasar Keperawatan. Jakarta: Salemba medika.

Lusianawati. (2010). Hubungan Stres Kerja Dengan Tingkat Empati Perawat Diruang Rawat Inap RSU PKU Muhammadiyah Yogyakarta.

http://opac.unisayogya.ac.id/1708 /1/NASKAH\%2OPUBLIKASI.pdf, diakses pada tanggal 31 januari 2017.

Machfoed, Ircham. 2010. Metodologi Penelitian Kuantitatif dan Kualitatif Bidang Kesehatan, Keperawatan, Kebidanan, Kedokteran. Yogyakarta : Fitramaya

Machfoedz. (2014). Metodologi Penelitian (kuantitatif \& kualitatif). Yogyakta: Fitramaya 
Muninjaya. 2013. Manajemen Kesehatan. Jakarta: EGC

Notoatmodjo. (2012). Metologi Penelitian Kesehatan. Jakarta: Rineka Cipta.

Nursalam. (2011). Konsep dan Penerapan Metodologi Penelitian Ilmu Keperawatan. Edisi II. Jakarta: Salemba Medika.

Nursalam. (2014). Metodologi Penelitian Ilmu Keperawatan Pendekatan Praktis edisi 3. Jakarta: Salemba Medika.

PPNI. (2014). Hasil survei PPNI tentang stres kerja.http://repository.unand.ac.id/ 22372/. Diakses 05 februari 2017

Priyoto. (2014). Komunikasi dan Sikap Empati Dalam Keperawatan. Jakarta: Graha Ilmu.

Setiadi. (2007). Konsep Dan Penulisan Riset Keperawatan. Yogyakarta: Graha ilmu

Setiyana. 2013. Pelayanan prima. Jakarta : EGC.

Supardi. 2012. Analisa stres kerja pada kondisi beban kerja. http://www.scribd.com/analisastres-kerja-dan-beban-keja. diakses pada tanggal 05 februari 2017.

Wijono, sutarto, (2006). Pengaruh Kepribadian Type A dan Peran Terhadap Stres Kerja Manajer Madya. Salatiga. 